\title{
Examination of Lifelong Learners' Preferences for Learning Materials and Methods within the Context of Various Demographic Characteristics
}

\author{
Hakan Altınpulluk*, Hakan Kılınç and Mehmet Fırat \\ Anadolu University, Open Education Faculty, Turkey
}

\section{ARTICLE INFO}

Keywords:

Lifelong Learning

Learning Materials

Learning Methods

\begin{abstract}
The aim of this study is to analyze the relationship between lifelong learners' preferences for learning materials and methods according to age, gender and working status variables. Since lifelong learners' preferences for learning materials are examined according to certain variables, the relational survey model, which is used in descriptive research, was considered appropriate to implement in this study. The study group of the research consists of 608 lifelong learners, who study at their second universities at least and receive education within the scope of second university without examination in the Faculty of Open Education, Anadolu University. The data were analyzed by using custom tables in SPSS 24.0 package program and descriptive statistics such as frequencies and percentages were used in the analysis of the data. The findings obtained from the statistical analyses of the research questions were presented under six sub-headings.
\end{abstract}

\section{Introduction}

In order to keep up with all kinds of digital transformation and technological developments in the 21 st century, individuals must constantly learn, update and refresh what they learn. Lifelong learning has emerged as a result of one's need for knowing and assessing him/herself, and developing his/her skills. Lifelong learning, which incorporates both formal and informal education, is defined as the process through which all kinds of values, skills, knowledge and qualities that individuals face during their lives are obtained and implemented in the daily life (Candy, 2003). Lifelong learning, which involves all kinds of informal education as well as formal education, facilitates the adaptation of individuals to the information society by contributing to the development of their knowledge and competences. The fact that learning by doing-experiencing in addition to formal and non-formal education are at the heart of lifelong learning shows that learning can take place at every stage of life (Gunuc, Odabaşı \& Kuzu, 2012). It can be argued that one of the most important concepts that the information society put forward in the 21 st century is lifelong learning. Even if the implementation methods may vary, the most important goal of this concept is to prepare the environments that enable individuals to continue their activities throughout their life by making them to learn how to learn. The concept of lifelong learning, which focuses on transforming societies, increasing the education level of individuals and strengthening the economy in line with these improvements, can only be realized by implementing the right education policies (Karakuş, 2013). 


\subsection{Purpose of the research}

The purpose of this study is to investigate the relationship between learning materials and learning methods preferred by lifelong learners who are educated under the scope of a second university based on various demographic characteristics. In this framework, answers to the following research questions are sought.

1. Is there a relationship between lifelong learners' preference for learning material and their age?

2. Is there a relationship between lifelong learners' preference for learning method and their age?

3. Is there a relationship between lifelong learners' preference for learning material and their gender?

4. Is there a relationship between lifelong learners' preference for learning method and their gender?

5. Is there a relationship between lifelong learners' preference for learning material and their working status?

6. Is there a relationship between lifelong learners' preference for learning method and their working status?

\section{Method}

\subsection{Research model}

In this study, the descriptive research method was used since it was aimed to examine the relationship between learning materials and methods preferred by lifelong learners who are educated under the second university without examination. According to Frankel, Wallen and Hyun (Fraenkel, Wallen \& Hyun, 2011), survey method, which is among descriptive methods, is used to collect data from a group of people who are a part of a large community to explain some of their views. Since the data was collected from a group of people studying at the Second University program under the Faculty of Open Education, Anadolu University, the study was designed according to the survey method. According to the relational survey model which is a sub-type of the survey models that enable to reveal the current situation, it is aimed to determine the existence and degree of covariation between two or more variables (Karasar, 2007). Since lifelong learners' preferences for learning materials are examined according to certain variables, relational survey model which is used in descriptive research was considered appropriate to implement in this study.

\subsection{Study group}

The study group of the research consists of lifelong learners $(n=608)$, who study at their second universities at least and receive education within the scope of second university without examination in the Faculty of Open Education, Anadolu University. When the distribution of the students in the study group is examined by gender, it is seen that $44.7 \%$ $(n=272)$ of the participants are female and $55.3 \%(n=336)$ are male. In terms of age distribution, there are 189 students $(31.1 \%)$ in the $15-24$ age group, 406 students $(66.8 \%)$ in the 25-54 age group, and 13 students $(2.1 \%)$ in the 55-64 age group. When the participants are examined by working status, it is observed that $187(30.8 \%)$ of the learners are not working, 177 (29.1\%) learners are working at the public sector, 187 (30.8\%) are working at the private sector, $18(3.0 \%)$ are retired and 39 students $(6.4 \%)$ marked the other option.

\subsection{Data collection tool and analysis process}

The Reasons for Second University Choice Questionnaire was used as data collection tool in the study. Data were analyzed through SPSS 24.0 package program by using custom table. Descriptive statistics such as frequencies and percentages were used in the analysis of the 
data. The data obtained from the research were presented in descriptive tables and interpretations were performed based on the frequency and percentage values observed in the cross tables. Thus, the sub-questions produced depending on the objective of the study were answered.

\section{Findings}

The findings obtained from the statistical analyses performed within the scope of the research questions are presented below.

3.1 The relationship between lifelong learners' preference for learning materials and their ages

Table 1.

The relationship between lifelong learners' preference for learning materials and their ages

\begin{tabular}{|c|c|c|c|c|c|c|c|}
\hline & & \multicolumn{6}{|c|}{ Age } \\
\hline & & \multicolumn{2}{|c|}{$15-24$} & \multicolumn{2}{|c|}{$25-54$} & \multicolumn{2}{|c|}{$55-64$} \\
\hline & & $\mathrm{n}$ & $\%$ & $\mathrm{n}$ & $\%$ & $\mathrm{n}$ & $\%$ \\
\hline \multirow{7}{*}{$\begin{array}{l}\text { What materials } \\
\text { do you learn } \\
\text { best from? }\end{array}$} & Printed Books & 101 & $53,4 \%$ & 225 & $55,4 \%$ & 8 & $61,5 \%$ \\
\hline & Digital Books & 11 & $5,8 \%$ & 43 & $10,6 \%$ & 3 & $23,1 \%$ \\
\hline & Video-Animation & 30 & $15,9 \%$ & 59 & $14,5 \%$ & 0 & $0,0 \%$ \\
\hline & Visual, Graphic and Drawing & 28 & $14,8 \%$ & 39 & $9,6 \%$ & 1 & $7,7 \%$ \\
\hline & Audio Lecture & 17 & $9,0 \%$ & 35 & $8,6 \%$ & 0 & $0,0 \%$ \\
\hline & Other & 2 & $1,1 \%$ & 5 & $1,2 \%$ & 1 & $7,7 \%$ \\
\hline & Total & 189 & $100 \%$ & 406 & $100 \%$ & 13 & $100 \%$ \\
\hline
\end{tabular}

As shown in Table 1, $101(53.4 \%)$ out of 189 people in the 15-24 age group prefer to learn from printed books. While 30 students $(15.9 \%)$ at this age group prefer to learn through video-animation, it is remarkable that digital book is the least preferred learning material with $5.8 \%$. 55.4\% of the participants in the 25-54 age group prefer printed books, while audio lecture is the least preferred learning material with $8.6 \%$ in this age group. On the other hand, printed books have the highest preference rate $(61.5 \%)$ in the 55-64 age group. Videoanimation and audio lecture were not preferred at all in this age group.

3.2 The relationship between lifelong learners' preference for learning methods and their ages

Table 2.

The relationship between lifelong learners' preference for learning methods and their ages

\begin{tabular}{|c|c|c|c|c|c|c|c|}
\hline & & \multicolumn{6}{|c|}{ Age } \\
\hline & & \multicolumn{2}{|c|}{$15-24$} & \multicolumn{2}{|c|}{$25-54$} & \multicolumn{2}{|c|}{$55-64$} \\
\hline & & $\mathrm{n}$ & $\%$ & $\mathrm{n}$ & $\%$ & $\mathrm{n}$ & $\%$ \\
\hline \multirow{9}{*}{$\begin{array}{l}\text { How do you } \\
\text { learn best? }\end{array}$} & By marking on the book & 34 & $18,0 \%$ & 111 & $27,3 \%$ & 7 & $53,8 \%$ \\
\hline & By taking notes on the notebook & 58 & $30,7 \%$ & 106 & $26,1 \%$ & 1 & $7,7 \%$ \\
\hline & By drawing, scribbling & 19 & $10,1 \%$ & 45 & $11,1 \%$ & 2 & $15,4 \%$ \\
\hline & By repeating & 13 & $6,9 \%$ & 50 & $12,3 \%$ & 3 & $23,1 \%$ \\
\hline & By discussing with someone & 19 & $10,1 \%$ & 28 & $6,9 \%$ & 0 & $0,0 \%$ \\
\hline & By explaining to someone & 28 & $14,8 \%$ & 32 & $7,9 \%$ & 0 & $0,0 \%$ \\
\hline & By listening from someone & 15 & $7,9 \%$ & 27 & $6,7 \%$ & 0 & $0,0 \%$ \\
\hline & By searching on the internet & 3 & $1,6 \%$ & 7 & $1,7 \%$ & 0 & $0,0 \%$ \\
\hline & Total & 189 & $100 \%$ & 406 & $100 \%$ & 13 & $100 \%$ \\
\hline
\end{tabular}


In Table 2, 30.7\% of lifelong learners between the ages of 15 and 24 prefer to work by taking notes on the notebook. Only $1.6 \%$ of learners in this age group work by searching on the internet. In the 25-54 age group, $27.3 \%$ of the students want to work by marking on the book. In this age group, the least preferred method is, again, searching on the internet $(1.7 \%)$. Lifelong learners between the ages of 55 and 64 also prefer to learn by marking on the book. 3.3 The relationship between lifelong learners' preference for learning materials and their genders

Table 3.

The relationship between lifelong learners' preference for learning materials and their genders

\begin{tabular}{llcccc}
\hline & & \multicolumn{2}{c}{ Gender } & \multicolumn{2}{c}{ Male } \\
\cline { 3 - 6 } & & $\mathrm{n}$ & $\%$ & $\mathrm{n}$ & $\%$ \\
\hline & Printed Books & 154 & $56,6 \%$ & 180 & $53,6 \%$ \\
& Digital Books & 21 & $7,7 \%$ & 36 & $10,7 \%$ \\
What materials & Video-Animation & 38 & $14,0 \%$ & 51 & $15,2 \%$ \\
do you learn & Visual, Graphic and Drawing & 29 & $10,7 \%$ & 39 & $11,6 \%$ \\
& Audio Lecture & 27 & $9,9 \%$ & 25 & $7,4 \%$ \\
& Other & 3 & $1,1 \%$ & 5 & $1,5 \%$ \\
& Total & 272 & $44,7 \%$ & 336 & $55,3 \%$ \\
\hline
\end{tabular}

As shown in Table 3, both females (56.6\%) and males (53.6\%) mostly prefer to work with printed books. Digital books is the last preference of females $(7.7 \%)$, while males' least preferred learning materials is audio lecture $(7.4 \%)$.

\subsection{The relationship between lifelong learners' preference for learning methods and their genders}

Table 4.

The relationship between lifelong learners' preference for learning methods and their genders

\begin{tabular}{|c|c|c|c|c|c|}
\hline & & \multicolumn{4}{|c|}{ Gender } \\
\hline & & \multicolumn{2}{|c|}{ Female } & \multicolumn{2}{|c|}{ Male } \\
\hline & & $\bar{n}$ & $\%$ & $\mathrm{n}$ & $\%$ \\
\hline \multirow{9}{*}{$\begin{array}{l}\text { How do you } \\
\text { learn best? }\end{array}$} & By marking on the book & 63 & $23,2 \%$ & 89 & $26,5 \%$ \\
\hline & By taking notes on the notebook & 90 & $33,1 \%$ & 75 & $22,3 \%$ \\
\hline & By drawing, scribbling & 27 & $9,9 \%$ & 39 & $11,6 \%$ \\
\hline & By repeating & 19 & $7,0 \%$ & 47 & $14,0 \%$ \\
\hline & By discussing with someone & 20 & $7,4 \%$ & 27 & $8,0 \%$ \\
\hline & By explaining to someone & 30 & $11,0 \%$ & 30 & $8,9 \%$ \\
\hline & By listening from someone & 19 & $7,0 \%$ & 23 & $6,8 \%$ \\
\hline & By searching on the internet & 4 & $1,5 \%$ & 6 & $1,8 \%$ \\
\hline & Total & 272 & $44,7 \%$ & 336 & $55,3 \%$ \\
\hline
\end{tabular}

As can be seen in Table 4, the majority of females (33.1\%) work by taking notes on the notebook. Women do not seem to prefer working by searching on the Internet (1.5\%). Males, on the other hand, mostly prefer to learn by marking on the books $(26.5 \%)$. Searching on the internet is the least popular method among males $(1,8 \%)$, as is the case with females. 
3.5 The relationship between lifelong learners' preference for learning materials and their working status

Table 5 .

The relationship between lifelong learners' preference for learning materials and their working status

\begin{tabular}{|c|c|c|c|c|c|c|c|c|c|c|c|}
\hline & \multicolumn{10}{|c|}{ Working Status } \\
\hline & & \multicolumn{2}{|c|}{ Not working } & \multicolumn{2}{|c|}{ Public } & \multicolumn{2}{|c|}{ Private Sector } & \multicolumn{2}{|c|}{ Retired } & \multicolumn{2}{|c|}{ Other } \\
\hline & & $\mathrm{n}$ & $\%$ & $\mathrm{n}$ & $\%$ & $\mathrm{n}$ & $\%$ & $\mathrm{n}$ & $\%$ & $\mathrm{n}$ & $\%$ \\
\hline \multirow{8}{*}{$\begin{array}{l}\text { What } \\
\text { materials } \\
\text { do you } \\
\text { learn best } \\
\text { from? }\end{array}$} & Printed Books & 111 & $59,4 \%$ & 98 & $55,4 \%$ & 89 & $47,6 \%$ & 13 & $72,2 \%$ & 23 & $59,0 \%$ \\
\hline & Digital Books & 6 & $3,2 \%$ & 17 & $9,6 \%$ & 28 & $15,0 \%$ & 3 & $16,7 \%$ & 3 & $7,7 \%$ \\
\hline & Video-Animation & 27 & $14,4 \%$ & 35 & $19,8 \%$ & 21 & $11,2 \%$ & 1 & $5,6 \%$ & 5 & $12,8 \%$ \\
\hline & $\begin{array}{l}\text { Visual, Graphic } \\
\text { and Drawing }\end{array}$ & 27 & $14,4 \%$ & 13 & $7,3 \%$ & 21 & $11,2 \%$ & 1 & $5,6 \%$ & 6 & $15,4 \%$ \\
\hline & Audio Lecture & 15 & $8,0 \%$ & 13 & $7,3 \%$ & 23 & $12,3 \%$ & 0 & $0,0 \%$ & 1 & $2,6 \%$ \\
\hline & Other & 1 & $0,5 \%$ & 1 & $0,6 \%$ & 5 & $2,7 \%$ & 0 & $0,0 \%$ & 1 & $2,6 \%$ \\
\hline & Total & 187 & $100 \%$ & 17 & $100 \%$ & 18 & $100 \%$ & 18 & $100 \%$ & 39 & $100 \%$ \\
\hline & & & & 7 & & 7 & & & & & \\
\hline
\end{tabular}

As can be seen in Table 5, most of the lifelong learners who do not work at any job (59.4\%) mostly prefer printed books. It is also seen that these learners prefer the digital book at the minimum level with $3.2 \%$. While $55.4 \%$ of public employees prefer printed books, "visual, graphic and drawing" and "audio lecture" are the least preferred materials with a rate of 7.3\%. The learners working at the private sector, again, mostly prefer printed books with $47.6 \%$. While the use of digital books is slightly higher in these learners with $15 \%$, "videoanimation" and "visual, graphic and drawing" are the least preferred materials with $11.2 \%$. Retired learners and those in the other category also prefer to benefit from printed books.

3.6 The relationship between lifelong learners' preference for learning methods and their working status

Table 6.

The relationship between lifelong learners' preference for learning methods and their working status

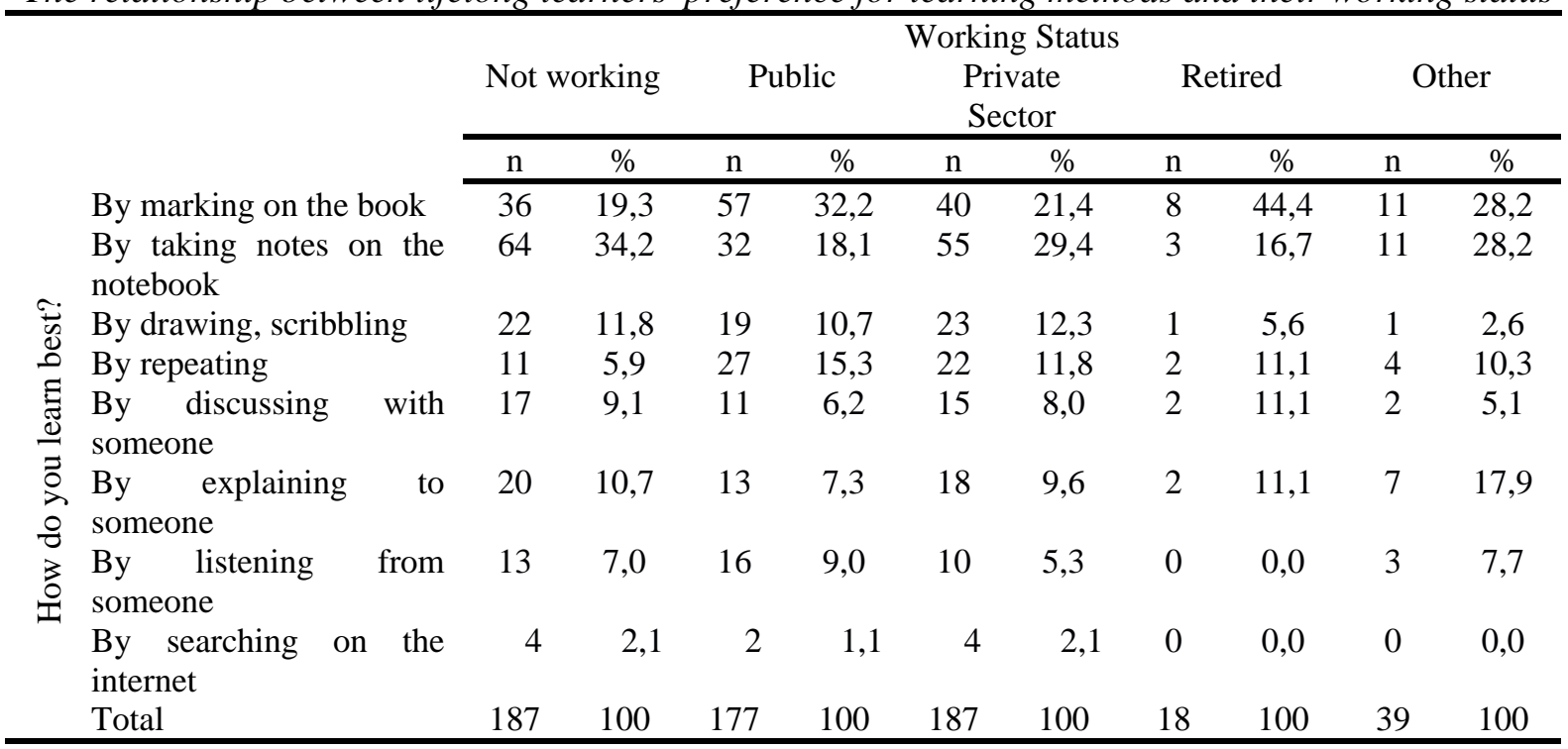

As shown in Table 6, 34.2\% of non-working learners prefer to work by taking notes on the notebook. Only $2.1 \%$ of the learners prefer the internet search method. While $32.2 \%$ of public employees prefer to learn by marking on the book, $29.4 \%$ of the learners working at the private sector prefer to work by taking notes on the notebook. Retired learners also 
predominantly prefer to learn by marking on the book. Under the scope of working status, the least preferred method is learning by searching on the Internet.

\section{Conclusion}

Lifelong learning has emerged as a consequence of realizing the increasing impact of learning throughout life and has been considered the most important way of dealing with problems such as globalization, knowledge economy, employment, disadvantaged groups and isolation from society. The goal of lifelong learning is to meet the educational needs of adults who cannot keep up with the age for failing to keep up with the pace of change or to fulfil their expectations, and to provide the necessary support for them to overcome the difficulties in the adaptation process. It is estimated that lifelong learning will become even more important in the future and play a major role in the transformation of societies.

The Faculty of Open Education at Anadolu University offers lifelong learning services in Turkey with its Second University without Exam program. This study which aims to examine the relationship between lifelong learners' preferences for learning methods and materials by their age, gender and working status has reached certain findings. One of the most striking findings is that despite the development of technological tools within the scope of lifelong learning, printed books is still the most widely preferred learning material by the learners. Although printed books have undergone several changes since the ancient times and the development of mass media has affected the development of printed books over time, they have always maintained their importance in education regardless of the place (Kaya, 2002). The importance of printed books has been revealed once again in this study. $54.9 \%$ of lifelong learners prefer to learn from printed books.

One of the findings of this study is that digital book is still not preferred much with respect to various demographic features. Woody et al. (2010) found that reading digital books is still not as common as printed books, which supports the findings of this study. In another study, Buzzetto-More et al. (2007) found that very few of the learners buy digital books instead of printed books.

In terms of learning methods, it has been revealed in the context of various demographic characteristics that lifelong learners learn by marking on the book and taking notes on the notebook. According to Annand (2008), even online materials are used after printed out by learners, which confirms the findings of this study. At this point, it is seen that reading on books, notebooks and printouts, underlining important points, marking caveats and highlighting, and taking notes with pens are still the most preferred learning methods for lifelong learners.

Some of the findings obtained in this study are rather striking. For example, it is noteworthy that 15-24-year-old learners, who are called the digital natives, do not prefer to use digital books, but prefer to work by taking notes on the notebooks and that they do not prefer to learn by searching on the internet. When analyzed in terms of gender, it is seen that women work by taking notes on the notebook while males prefer to mark on the books. In the context of working status, it is also confirmed, as an expected result, in this study that retired learners do not give up printed books and prefer to work by marking on their books.

\section{References}

Annand, D. (2008). Learning efficacy and cost-effectiveness of print versus e-book instructional material in an introductory financial accounting course. Journal of Interactive Online Learning, 7(2), 152-164.Beck, K. and Ralph, J. (1994). Patterns Generates Architectures. Proceedings of European Conference of Object-Oriented Programming. Bologna, Italy, pp. 139-149. 
Buzzetto-More, N., Sweat-Guy, R., \& Elobaid, M. (2007). Reading in a digital age: E-books are students ready for this learning object. Interdisciplinary Journal of Knowledge and Learning Objects, 3(1), 239-250.

Candy, P. C. (2003). Lifelong Learning and Information Literacy. Report for U.S. National Commission on Libraries and Information Science and National Forum on Information Literacy.

Fraenkel, J. R., Wallen, N. E., \& Hyun, H. H. (2011). How to design and evaluate research in education. New York: McGraw-Hill Humanities/Social Sciences/Languages.

Gunuc, S., Odabaşı, H. F., \& Kuzu, A. (2012). Yaşam boyu öğrenmeyi etkileyen faktörler. Gaziantep University Journal of Social Sciences, 11(2), 309-325.

Karakuş, C. (2013). Meslek yüksekokulu öğrencilerinin yaşam boyu öğrenme yeterlikleri. Ĕgitim ve Öğretim Araştırmaları Dergisi, 2(3), 26-35.

Karasar, N. (2007). Bilimsel araştırma yöntemi. Nobel Yayın Dağıtım.

Kaya, Z. (2002). Uzaktan eğitim. Ankara: Pegem Publishing.

Woody, W. D., Daniel, D. B., \& Baker, C. A. (2010). E-books or textbooks: Students prefer textbooks. Computers \& Education, 55(3), 945-948. 